\title{
Cash Conversion Cycle Management on the Financial Performance of Building Materials/Chemical and Paint Manufacturing Companies in Nigeria.
}

\author{
Okpe Innocent Ikechukwu ${ }^{1}$ and Duru Anastesia Nwakaego (Ph.D $)^{2}$ \\ ${ }^{1,2}$ Department of Accountancy, Enugu State University of Science and Technology, Enugu State, Nigeria.
}

\begin{abstract}
The study examined the effect of cash conversion cycle on the Financial performance of Building materials/chemical and paint manufacturing companies in Nigeria. Cash conversion cycle, receivable ratio, payable ratio, and inventory ratio are the variables studied in this study. Data were sourced from the annual reports of Health care companies in Nigeria. Generalized Least square multiple regression analytical tool was used to test the Hypotheses. The findings show that, Inventory ratio and Accounts receivable ratio had significant and positive effect on firms profitability, accounts payable ratio and Cash conversion cycle had positive and non- significant effect on firms' profitability.
\end{abstract}

Keywords: Cash Conversion, Financial Performance and multiples regression

\section{Introduction}

Cash conversion cycle (CCC) has been considered a useful measure of firms' effective working capital management, especially the cash management. It is also a powerful performance measure for assisting how well a company is managing its working capital. A short cash conversion cycle is indirectly related to firm value. It also indicates that the firm is collecting the receivables as quickly as possible, and delaying the payments of suppliers as slowly as possible. This leads to high net present value. Cash conversion cycle is an addictive measure of funds that are committed, that is tied inventories and receivables less payments that are deferred to suppliers. It has been interpreted as the cash outlays that arise during the production of output, and cash inflows that result from the sale of the output, and the collection of accounts receivables. Besley and Brigham(2005),described cash conversion cycle as the length of time from the payment for the purchase of raw materials to manufacture products until the collection of account receivable associated with high profitability, because it improves the efficiency of using the working capital.

\section{Statement of Problem}

Some Nigeria workers were forcefully disengaged from their services example Ajaokuta steel industry reduced their staff from 5000 to 1000 in 2007. Some of the manufacturing firms that are still in business and are listed in Nigeria stock exchange cannot pay dividend to shareholder in their companies example champion breweries has not paid since1988, golden breweries has not paid since 1997 (Salandeen, 2001). it is as a result of the above problem that the researchers deemed it necessary to examine the effect of cash conversion cycle on the profitability of Health care manufacturing companies quoted in Nigerian stock exchange.

\section{Objectives of the Study}

The general objective of this study is to examine the effect of cash conversion cycle on the profitability of Building materials/chemical and paint manufacturing companies in Nigeria, while the specific objectives include;

(1) To examine the effect of cash conversion cycle on profitability.

(2) To ascertain the effect of accounts receivable ratio on profitability.

(3) To determine the effect of accounts payable ratio on profitability.

(4) To ascertain the effect of inventory ratio on profitability of Building materials/chemical and paint manufacturing companies in Nigeria.

\section{Hypotheses.}

(1) Cash conversion cycle has no effect on profitability.

(2) Accounts receivable ratio has no effect on profitability

(3) Accounts payable ratio has no effect on the profitability. 
(4) Inventory ratio has no effect on the profitability of Building materials/chemical and paint manufacturing companies in Nigeria.

\section{Literature Review}

Charitou, et al (2010) in their study empirically investigated the effect of working capital management on firm's financial performance in an emerging market. They hypothesized that working capital management leads to improved profitability. Their data set consists of firms listed in the Cyprus Stock exchange for the Period 1998-2007. Using multivariate regression analysis, their results supported their hypotheses. Specifically, their results indicated that the cash conversion cycle and all its major components namely, days in inventory, days in sales outstanding and creditor's payment-period were associated with the firms' profitability. They opined that the results of this study should be of great importance to managers and major stakeholders, such as investors, creditors and financial analysts, especially after the recent global financial crisis and the latest collapse of giant organizations worldwide.

Deloof,(2003) have investigates relationship between working capital management and corporate profitability for a sample of 1009 large Belgian non financial firm for the period 1992-1996. The result from the analysis showed that there was a negative relationship between profitability that measure by gross operating income and cash conversion circle as well as number of days accounts receivable and inventories. He suggested that mangers can increase corporate profitability by reducing the number of day's Accounts receivable and inventories less profitable firms waited longer to pay their bills.

Gill et al (2010) seek to extend Tryfonidis findings regarding the relationship between working capital management and profitability. A sample of 88 American firms listed on New York stock Exchange for a period of 3years from 2005-2007. They found statistically significant relationship between the cash conversion cycle and profitability

Howorth (2003) in his study on the field of working capital management focuses on the routines employed by firms. The research showed that firms which focus on cash management were larger, with fewer cash sales, more seasonality and possibly more cash flow problems. While smaller firms focused more on stock management and less profitable firms were focused on credit management routine. It was suggested that high growth firms follow a more reluctant credit policy towards their customers, while they tie up more capital in the form of inventory. Account payables will increase due to better relations of suppliers with financial institutions which divert this advantage of financial cost to their client (Peterssen and Rajan 2007).

Falope and Ajilore (2009) examined the working capital management and corporate, profitability; Evidence from panel data: analysis of selected quoted companies in Nigeria. They used the sample of Nigerian quoted non-financial firms for the period 1996-2005. The study found a significant negative relationship between net operating profitability and the average collecting period inventory turnover in days, average payment period and cash conversion cycle for a sample of fifty Nigerian firms listed on the Nigeria stock Exchange. Furthermore, the study found no significant variation in the effects of working capital management between large and small firms. These result suggest that management can create value for their working capital in more efficient way by reducing the number of day accounts receivable and inventories to a reasonable minimum.

Karaduman, et al (2011), examines the empirical relationship between efficiency of working capital management and corporate profitability of selected companied in the Istanbul stock exchange for the period of 2005 - 2009. The panel data methods were employed in order to analyze the mentioned relationship. The cash conversion cycle (CCC) was used as a measure of working capital management efficiency, and return on assets (ROA) used as a measure of profitability. He found out that reducing cash conversion circle (CCC) positively affects return on assets.

Padachi (2006) in his study also studies on the trends in working capital management and its impact on firms' performance: analysis of Mauritian small manufacturing firms, to identify the causes for any significant difference between the industries. The dependent variable return on total assets is used as a measure of profitability and the relation between working capital management and corporate profitability was investigated for a sample of 58 small manufacturing firms, using panel data analysis for the period 1998-2003. The regression result shows that high investment is inventories and renewable is associated with lower profitability. The key variable used in the analysis was inventories days, accounts receivables days, accounts payable days and cash conversion cycle. A strong significant relationship between working capital management and profitability has been found in pervious empirical work. An analysis of the liquidity, profitability and operational efficiency of the five industries trend in the short - term component of working capital financing.

Lyrondi and Lazardis (2000) investigate the cash conversion cycle and liquidity position of the food industry in cycle as a liquidity level indicator of the food industry in Greece and tried to determine its relationship with the traditional liquidity measurement and profitability measurement on return on investment, return on equity and net profit margin, they found significant, positive relationship between cash conversion 
cycle and payable deferred period. The relationship between liquidity measurement variables and profitable measurement variable was not statistically significant and there was no relationship between cash conversion cycle and leverage ratio. To determine the solvency level of firms according to existing obligation of firms different techniques may apply as measurement of liquidity Current ration, quick ratio and cash ratio are among the most traditional liquidity measurement techniques and the most recent dynamic techniques, cash conversion cycle is applied for measurement of liquidity level of firms. The relationship of these traditional and modern liquidity measurement techniques are studies by Lyroudi and MC Carty (1993) for small U.S companies for the period $1984-1988$ and they found that cash conversion cycle was negatively related with the study revealed difference between current ratio but positively related with quick ration. In addition, the study revealed difference between the concept of cash conversion cycle in manufacturing retail, wholesale and Service industries. The advantage of using modern liquidity measurement technique is that it will help to evaluate working capital change and it facilities the monitoring and controlling of its components, receivable inventories and payable. The smaller value of cash conversion cycle shows that, the quicker the firms can recover cash from sales of finished products and the more cash will have hence this will lead to have more liquid assets by firms. If cash conversion is high, it will take longer time recover cash, thus high cash conversion cycle implied an existence of problem in liquidity, lyroudis and lazardis (2000)

Lazaridis,I. and Trynidis,D. (2006) have also investigate the relationship between working capital management and profitability of listed company in the Athens Stock Exchange. A sample of 131 listed companies for a period of 2001-2004, was used to examine this relationship. The result from regression analysis indicated that there was a statistical significance between profitability measured through, operating profit and the cash conversion cycle. From those results they claimed that the managers could create value for shareholders by handling correctly the cash conversion cycle and keeping each different component to an optimal level.

Muchina and Kiano (2011) in their study analyzes the influence of working capital management on firms' profitability in Kenya. They used fixed panel data of 232 firms. The result indicated that the average debtor day, stock turnover period and the cash conversion cycle are significantly affecting the profitability of the firms. They found out also that the manufacturing firms are in general facing problems with their collection and payment policies. Moreover, the financial leverage, ratio of current asset to current liability and firm size also have significant effect on the firm profitability. The study also concluded that SMES in Kenya are following conservative working capital management policy and payment policy. They suggested that the effective polices must be formulated for the individual component of working capital and that efficient management and financing of working capital (current assets and current liabilities) can increase the operating profitability of manufacturing firms. For efficient working capital management, specialized persons in the field of finance should be hired by the firms for expert advice on working capital management in the manufacturing sector.

Raheham and Nasr (2007) have selected a sample of 94 Pakistani firms on Karachi stock exchange for a period of 6 years from 1999- 2004 to study the effect of different variables of working capital management on the net operating profitability. From the result of the study, they showed that there was a negative relationship between variables of working capital management including the average collection period, inventory turnover in days cash conversion cycle and profitability. Besides, they also indicated the size of the firm. Measured by natural logarithm of sales and profitability had a positive relationship.

\section{Methodology}

\section{Research Design}

The Research Design used in this study was Ex-post facto research design. It was used because it involved events that have taken place in the past.

\section{Population and sample size of the study}

The population of this study is all the companies in Building materials/chemical and paint manufacturing firms in Nigeria, while the sample size is dependent on Data availability.

\section{Nature and sources of Data.}

The study used only secondary data extracted from annual report and statement of accounts of the companies under study. The data for this study include, cash conversion cycle, receivables, payables, inventories, and profit before tax.

\section{Description of variables. Dependent Variable (Profitability)}

The dependent variable in the study is firm's profitability. In order to analyze the effect of cash conversion cycle on the firm's profitability, the return on assets will be used as dependent variable. This is because the return on assets (ROA) is an indicator of managerial efficiency. (Lazaridis and trynids, (2006), Delof (2003), Falope and Ajilore, and Karaduman et al (2011). 


\author{
PBT \\ Profitability Total assets
}

\title{
Cash Conversion Cycle ratio (CCC)
}

\section{Independent Variables}

Cash conversion cycle is the rate cash flows from the suppliers to inventory to accounts receivable and back into cash. It is therefore an additive measure of funds that are committed ie tied inventories and receivables less payments that are deferred to suppliers. It has been interpreted as the cash outlays that arise during the production of output and the cash inflows that result from the sale of the output and the collection of the accounts receivable. The CCC is calculated by subtracting the payables and the inventories from the receivables. ( Gill et al 2010, Karaduman et al 2011, Kwasi 2010, Deloof 2003).

\section{Accounts Receivable Ratio}

Accounts receivables are customers who have not yet made payment for goods or services which the firm has provided. In this respect account receivable is calculated as accounts receivable divided by sales. This variable represents the receivable that the firm will collect from its customers (Basley and Bring ham, 2005 Samiloglu and Demrigunes, 2008).

Account receivable $=$ $\underline{\underline{\text { Receivables }}}$ Sales

\section{Accounts Payable Ratio}

Accounts payables are customers who have not yet made payment for goods or services which the firm has provided. In this respect account receivable is calculated as accounts payables divided by cost of sales. This variable represents the payables that the firm will pay from to customers (Basley and Bringham, 2005 Samiloglu and Demrigunes, 2008).

Account payables =

payables

Cost of sales

\section{Inventory Turnover Ratio}

Inventories are list of stocks of raw materials, work in progress or finished goods, waiting to be consumed in production or to be sold. Inventory ratio (INV) is calculated as inventories /purchases or cost of sales. The variable represents the rate stocks are held by the firm. Longer storage represents a greater investment in inventory for a particular level of operation Chariton et al[ 2010], Ghosh and Maji[2004].

\section{Inventory turnover ratio $=$}

\section{Inventories}

\section{Purchase/cost of sales}

\section{Technique for the Test of Hypotheses}

The Analytical tool used in this study for the test of Hypotheses is multiple regressions.

Multiple regression is a statistical tool for understanding the relationship between two or more variables, it allows for much more flexibility. Since we know that life is so complicated that it takes more than two variables to even begin to explain/predict why things are the way they are, and a new tool is needed i.e. multiple regression statistical tool.

This tool allows us to examine how independent variables are related to a dependent variable. Once you have identified how this multiple variables relate to your dependent variable, you can take information about all of the independent variables and use it to make much more powerful and accurate predictions about why things are the way they are. This process is known as multiple regressions. Multiple regressions is very advanced statistical tool and it is extremely powerful when you are trying to develop a "model" for predicting a wide variety of outcomes. It is more amenable to ceteris paribus analysis because it allows us to explicitly control for many other factors that simultaneously affect the dependent variable. This is important both for testing economic theories and for evaluation policy effect when we must rely on non-experimental data. Multiple regression models can accommodate many explanatory variables that may be correlated, we can infer casualty in cases where simple regression analysis would be misleading. It can also be used to build better models for predicting the dependent variable. Since return on total Asset will be used to measure dependent variable (Profitability of the study and the independent variables which are; Cash Conversion Cycle, Debt ratio, 
and sales growth rate.. Multiple regression technique is used to measure the effect the independent variables have on the dependent variable

$$
\mathrm{Y}=\mathrm{B}_{0}+\mathrm{B}_{1}+\mathrm{B}_{2} \ldots \ldots \ldots \ldots \mathrm{B}_{4}+\mathrm{U}_{\mathrm{i}}
$$

\section{Model specification}

In this study, the independent and dependent variables are used into an equation called multiple regressions. To express the model of multiple regressions in equation modified to suit the respective hypotheses. This study is a time series study that covers $2000-2011$.

$\mathrm{Y}=\mathrm{B}_{0}+\mathrm{B}_{1}+\mathrm{B}_{2+} \cdot \mathrm{B}_{3}+\mathrm{B}_{4}+\mathrm{U}_{1}$

Where,

$\mathrm{Y}=$ profitability

$\mathrm{B}_{1}=$ Cash Conversion cycle

B2=Accounts Receivable ratio

$\mathrm{B} 3=$ Accounts payable ratio

B4=Inventory ratio

$\mathrm{Bo}=$ the intercept of the regression line,

$\mathrm{U} 1=$ the error term

To test the competing views on the ( cash conversion cycle, receivable ratio, payable ratio, inventory ratio) in Nigeria, we modify the multiple linear regression in equation

Profitability $\left.=\mathrm{B}_{0}+\mathrm{B}_{1}(\mathrm{CCC})+\mathrm{B}_{2}(\mathrm{AR})+\mathrm{B}_{3}(\mathrm{AP})+\right)+\mathrm{B}_{4}(\mathrm{INV})+\mathrm{U}_{\mathrm{i}}$

Where, profitability is financial performance, $\mathrm{CCC}$ is cash conversion cycle, $\mathrm{AR}$ is Accounts Receivable,AP is Accounts payable,INV is inventory ratio.

Profitability $=B o+B 1(C C C]+B 2[S L] B 3(D T)+U \mathrm{i}$

\section{Computing the Multiple Regression Analyses}

First, values of critical indices in the management of the cash conversion cycle of in Building materials/chemical and paint Nigerian manufacturing firms in Nigeria obtained from Nigeria Stock Exchange were recalculated using the formulae listed in above to achieve the final data used for this study. Secondly the computed data were further subjected to multiple regression analysis. In analyzing the computed data for the variables involved in the study, it was necessary to employ four functional models of multiple regression in order to determine and select the model that best fitted the analysis. Thus the four multiple regression models employed in the analysis include the linear, semi log, double log and exponential regression models. They are implicitly expressed as follows:

a) Linear regression model:

Profitability $=\mathrm{Bo}+\mathrm{B} 1(\mathrm{CCC})+\mathrm{B} 2(\mathrm{AR})+\mathrm{B} 3(\mathrm{AP})+\mathrm{B} 4(\mathrm{INV})+\mathrm{U} 1$

b) Semi log regression model:

$$
\text { Profitability }=\operatorname{LogBo}+\operatorname{LogB} 1(C C C)+\operatorname{LogB} 2(D T)+\operatorname{LogB} 3(\text { SL })+B 4(I N V)+U 1
$$

c) Double log regression model:

$\log$ Profitability $=\operatorname{LogBo}+\operatorname{LogB} 1(C C C)+\operatorname{LogB} 2(A R) \operatorname{LogB} 3(A P)+B 4(I N V)+U 1$

d) Exponential regression model:

LogProfitability $=$ Bo + B1 $($ CCC $)+$ B2(DTAR $)+B 3(A P)+B 4(I N V)+U 1$

After obtaining the results of the four functional multiple regression models, decisions were therefore taken on which among them should be chosen as the best fit model in the analysis. The choice models were then used in the interpretation of the results. Decision and choice of the best fit model were fundamentally based on the following: a) the one with highest number of significant variables b) significance of F-ratio which measures the fitness of a model in using the independent variables to explain the dependent variable c) the magnitude of the coefficient of multiple determinations $\left(\mathrm{R}^{2}\right)$. Although decisions on the choice of models were based mostly on ones with highest number significant variables, result of the analysis must necessarily show significant Fratio. The coefficients of multiple determination $\left(\mathrm{R}^{2}\right)$ were employed in the study to quantify extent of variation in the dependent variable (profitability ratio) caused by the explanatory (independent) variables considered in the study.

Raw Data for Benue Cement Company Nigeria Plc.

\begin{tabular}{|l|l|l|l|l|l|}
\hline Years & $\begin{array}{l}\text { Return on } \\
\text { Asset Ratio }\end{array}$ & $\begin{array}{l}\text { Accounts } \\
\text { Receivable } \\
\text { Ratio }\end{array}$ & $\begin{array}{l}\text { Inventory } \\
\text { Turnover } \\
\text { Ratio }\end{array}$ & $\begin{array}{l}\text { Accounts } \\
\text { Payable Ratio }\end{array}$ & $\begin{array}{l}\text { Cash Conversion } \\
\text { Cycle Ratio }\end{array}$ \\
\hline 2000 & -0.10239 & 0.257883 & 2.192216 & 3.416137 & -5.35047 \\
\hline 2001 & -0.27937 & 0.309324 & $1, .230452$ & 2.4361 & -3.35723 \\
\hline
\end{tabular}


Cash Conversion cycle Management on the Financial Performance of Building Materials/Chemical....

\begin{tabular}{|l|l|l|l|l|l|}
\hline 2002 & -0.48596 & 0.417114 & 1.730596 & 5.679208 & -6.99269 \\
\hline 2003 & -0.47319 & 0.614822 & 0.158396 & 3.175943 & -2.71952 \\
\hline 2004 & -0.12134 & 0 & 0 & 0 & 0 \\
\hline 2005 & -0.06948 & 0.243327 & 0.542425 & 2.003753 & -2.30285 \\
\hline 2006 & 0.061145 & 0.277999 & 0.120833 & 1.405418 & -1.24825 \\
\hline 2007 & 0.050877 & 0.30078 & 0.14593 & 1.417717 & -1.26287 \\
\hline 2008 & -0.49101 & 0.35029 & 0.122604 & 1.224063 & -0.99638 \\
\hline 2009 & -0.09077 & 0.616123 & 2.725822 & 15.7122 & -17.8219 \\
\hline 2010 & -0.08465 & 0.618571 & 18.98004 & 12.11783 & -30.4793 \\
\hline 2011 & -0.1001 & 0.573751 & 17.44545 & 13.06192 & -29.9336 \\
\hline
\end{tabular}

Source: Author's Computation from Annual Accounts of Firm 2000-2011.

This company did not make profit in almost all the years, it was in 2006 and 2007 that they made little profit. They had more to receive than to pay. Inventory ratio was higher in the year 2000 and 2009.

Raw Data for Berger Paints Nigeria Plc.

\begin{tabular}{|l|l|l|l|l|l|}
\hline Years & $\begin{array}{l}\text { Return } \\
\text { Asset Ratio }\end{array}$ & $\begin{array}{l}\text { Accounts } \\
\text { Receivable } \\
\text { Ratio }\end{array}$ & $\begin{array}{l}\text { InventoryTurnover } \\
\text { Ratio }\end{array}$ & $\begin{array}{l}\text { Accounts } \\
\text { Payable } \\
\text { Ratio }\end{array}$ & $\begin{array}{l}\text { Cash } \\
\text { Conversion } \\
\text { Cycle Ratio }\end{array}$ \\
\hline 2000 & 0.040842 & 0.225659 & 0.624668 & 0.711688 & -1.1107 \\
\hline 2001 & 0.149082 & 0.015042 & 0.47907 & 0.520509 & -0.98454 \\
\hline 2002 & 0.104144 & 0.029615 & 0.623666 & 0.887832 & -1.48188 \\
\hline 2003 & 0.027384 & 0.304388 & 0.344477 & 0.326061 & -0.36615 \\
\hline 2004 & 0.101776 & 0.185786 & 0.374117 & 0.199954 & -0.38828 \\
\hline 2005 & -0.03298 & 0.163377 & 0.345622 & 0.167599 & -0.34984 \\
\hline 2006 & 0.055236 & 0.127628 & 0.265374 & 0.145622 & -0.28337 \\
\hline 2007 & 0.105111 & 0.113769 & 0.316593 & 0.142209 & -0.34503 \\
\hline 2008 & 0.119973 & 0.067981 & 0.214389 & 0.107955 & -0.25436 \\
\hline 2009 & 0.141529 & 0.086668 & 0.22027 & 0.117995 & -0.2516 \\
\hline 2010 & 0.199542 & 0.075142 & 0.354545 & 0.098011 & -0.37741 \\
\hline 2011 & 0.09189 & 0.041688 & 0.35829 & 0.15541 & -0.47201 \\
\hline
\end{tabular}

Source: Author's Computation from Annual Accounts of Firm 2000-2011.

The return on asset ratio of this company is low. Receivable ratio is low and their payable ratio is also low. The company had low rate of Inventory. Their CCC ratio was low.

Raw Data for Premier Paints Nigeria Plc.

\begin{tabular}{|l|l|l|l|l|l|}
\hline Years & $\begin{array}{l}\text { Return on } \\
\text { Asset Ratio }\end{array}$ & $\begin{array}{l}\text { Accounts } \\
\text { Receivable } \\
\text { Ratio }\end{array}$ & $\begin{array}{l}\text { InventoryTurnover } \\
\text { Ratio }\end{array}$ & $\begin{array}{l}\text { Accounts } \\
\text { Payable } \\
\text { Ratio }\end{array}$ & $\begin{array}{l}\text { Cash } \\
\text { Cycle Ratio }\end{array}$ \\
\hline 2000 & 0.031775 & 0.220372 & 0.090847 & 0.235076 & -0.10555 \\
\hline 2001 & -0.01297 & 0.188504 & 0.126416 & 0.244712 & -0.18262 \\
\hline 2002 & -0.04412 & 0.269069 & 0.140902 & 0.347373 & -0.21921 \\
\hline 2003 & -0.07276 & 0.260572 & 0.144533 & 0.371088 & -0.25505 \\
\hline 2004 & -0.03865 & 0.139605 & 0.094559 & 0.216466 & -0.17142 \\
\hline 2005 & 0.033165 & 0.15418 & 0.134137 & 0.245011 & -0.22497 \\
\hline 2006 & 0.059564 & 0.075673 & 0.215312 & 0.321044 & -0.46068 \\
\hline 2007 & 0.042811 & 0.119833 & 0.203366 & 0.043095 & -0.12663 \\
\hline 2008 & 0.042385 & 0.114605 & 0.219709 & 0.36006 & -0.46516 \\
\hline 2009 & -0.07876 & 0.138092 & 0.205996 & 0.566807 & -0.63471 \\
\hline 2010 & -0.31878 & 0.089328 & 0.075798 & 0.798313 & -0.78478 \\
\hline 2011 & -0.33598 & 0.121703 & 0.128706 & 0.918849 & -0.92585 \\
\hline
\end{tabular}

Source: Author's Computation from Annual Accounts of Firm 2000-2011.

This company did not make profit in many years, it was only in $2005-2008$ that they made little profit. They also have more to pay than to receive. The Inventory ratio is also low. Their CCC was also low and negative in all the years.

\section{Test of Hypotheses}

Hypotheses one

HO : Cash conversion cycle has no effect on profitability.

Hi: Cash conversion cycle has effect on profitability.(see table below)

\section{Hypothesis two}

Ho: Accounts receivable ratio has no effect on profitability 
Hi: Accounts receivable ratio has effect on profitability(see table below)

\section{Hypothesis three}

Ho: Accounts payable ratio has no effect on profitability

Hi: Accounts payable ratio has effect on profitability

\section{Hypothesis four}

Ho: Accounts Inventory ratio has no effect on profitability

Hi: Accounts Inventory ratio has effect on profitability(see table below)

Multiple Regression Analysis showing the relationship between Profitability ratio and AR, INV, AP, CCC, of Health Care firms in Nigeria

\begin{tabular}{|l|l|l|l|l|}
\hline Variables & $\begin{array}{l}\text { Linear } \\
\text { Regression }\end{array}$ & Semi Log Regression & $\begin{array}{l}\text { Double Log } \\
\text { Regression }\end{array}$ & Exponential Regression \\
\hline Constant & $-0.102^{*}$ & -0.048 & $-0.690^{*}$ & 0.124 \\
& $(-1.732)$ & $(-0.923)$ & $(-1.867)$ & $(0.417)$ \\
\hline Accounts Receivable Ratio & 0.000 & 0.057 & -0.043 & 0.008 \\
$($ AR) & $(-0.050)$ & $(1.357)$ & $(-0.146)$ & $(0.238)$ \\
\hline Inventory Turnover Ratio (INV) & 0.039 & 0.071 & -0.271 & -0.024 \\
& $(0.0617)$ & $(1.217)$ & $(-0.657)$ & $(-0.076)$ \\
\hline Accounts Payable Ratio (AP) & -0.024 & -0.027 & -0.078 & -0.166 \\
& $(-0.439)$ & $(-0.494)$ & $(-0.200)$ & $(-0.419)$ \\
\hline Cash Conversion Cycle Ratio & 0.019 & -0.078 & -0.478 & -0.023 \\
(CCC) & $(0.0345)$ & $(-1.018)$ & $(-0.883)$ & $(-0.084)$ \\
\hline $\mathrm{R}^{2}$ & 0.469 & 0.579 & 0.147 & 0.337 \\
\hline Adjusted R & 0.336 & 0.474 & -0.066 & 0.172 \\
\hline F-Ratio & $3.532^{* * *}$ & $5.510^{* * *}$ & 0.688 & $2.036^{*}$ \\
\hline
\end{tabular}

NB: 1.Profitability=Bo $+B i(A R) i i+B i(S T O) i i+B i(A P) i i+B i(C C C) i i+B i(L Q) i i+B 2 D T($ control $) 2 i+$ $B 2 S L($ control $) 2 i+U \mathrm{i}$

2. Also, $1 \%, 5 \%, 10 \%$ levels of significance are represented by $* * * ; * *$ and $*$ respectively

3. Values in brackets are coefficients while those outside brackets are t-values of the variables

The results of multiple regression analyses for the variables influencing the profitability ratio of Healthcare firms in Nigeria were summarized in Table 4.3.3 above. The Results showed that out of the four functional models of the multiple regression calculated, the Semi log Regression model was chosen because it has the highest number of significant variables as well as a very significant F-ratio (5.510***) value which indicated that the choice model best fitted the analysis. Also, the results of the analysis revealed an $\mathrm{R}^{2}$ value of 0.579 thus indicating that $57.9 \%$ variation in the profitability ratio (dependent variable) of Healthcare firms in Nigeria was accounted for by the explanatory (independent) variables considered in the analysis. Specifically the results showed that AR, INV had significant positive relationships with the industries' profitability ratio at $1 \%$ level of significance. This implies that a unit increases in values of AR, INV and shall bring about corresponding increases in the profitability ratio of Breweries industries in Nigeria. On the other hand, the industries' AP and CCC had negative and non-significant relationship with the profitability ratio at $1 \%$ levels of significance. This means that unit increase in the value of AP and CCC shall bring about corresponding decrease in the profitability ratio of Building/Chemical and Paint industries in Nigeria

\section{Conclusion}

The cash conversion cycle is a very powerful tool for examining how well a manufacturing company's working capital is being managed. The researchers concluded this work by observing that both AR and INV had significant positive effect on the Financial Performance (Profitability) of Building materials/chemical and paint companies in Nigeria. It was also found out that AP and CCC had negative but non-significant effect on profitability of these companies under study.

\section{References}

[1] Charitou. M.S. Elfani, M. Lois, P. (2010). The effect of marking capital management on firm's profitability: Empirical Evidence from an Emerging market, Journal of Business and economic Research, 8, (12),

[2] Ching, H.Y. Novazzi, A. and Gerab, F. (2011). Relationship between working capital management and profitability in Brazilian listed companies. Journal of global Business and Economics, 3,75 .

[3] Deloof, M. (2003). Does working capital management affect profitability of Belgian firm? Journal of Business finance and Accounting 30, (3 and 4), 573-587.

[4] Falope, O. I. and Ajilore, O.T. (2009). Working capital management and corporate profitability Evidence from panel Data Analysis of selected Quoted companies in Nigeria, research Journal of business management, 3, $73-84$. 
[5] Howorth, C.P. (2003). The focus of working capital management in Uk small firms. management accounting research, research 14, 97-111, Blackwell publishing.

[6] Gill, A. Biger, N. and Atnur, (2010). The relationship between working capital, management and profitability Evidence from the United state, Business and Economic Journal, vol. 2010, Bej - 10, 1-9.

[7] Karaduman, H.A. Aknas, H.E. Caliskan, A.O. and Durer, S. (2011). The relationship between working capital management and profitability. Evidence from an Emerging market, International research Journal of Finance and Economics, Issue 62-67.

[8] Kwasi, S.K. (2010). Working capital management and firms performance. An Analysis of Ghanaian oil marketing firms, INTEQ. GH. Tel: 233-205600002/233-24-9276087

[9] Lazaridisi, I. and Trynidis, D. (2006). Relationship between working capital management and profitability of listed companies in the Athens stock exchange", Journal if financial management and Analysis, 19, (1), 26-35.

[10] Lyroadi, and Lazadis, (2000). Short term financial management of business increases and in Cyprus Business and Economic society international.

[11] Muchina ,s, and Kiano, E. (2011). Influence of working capital management on firms profitability: A case SMES in Kenya, International Business management, 5, (5), $279-286$.

[12] Murugesu, T.(2013).Effect of cash conversion cycle on profitability:Listed Plantation Companies in Sri Lanka,Research Journal of Finance and Accounting, 4(18).

[13] Padachi, K. (2006). Trends in working capital management and its impact on firm's performance: An analysis of Mauritian small manufacturing firms. International review of business research papers. 2, (2), $45-58$.

[14] Raheman, A. and Nasr, M. (2007). Working capital management and profitability. Case of Pakistani firms, international review of business research papers 3, (1), 279-300. 